Dangerous to rely on non-reliance or entire agreement clauses any representation, warranty, or assurance made or given by any other party or any other person (whether negligently or innocently made), whether or not in writing, at any time prior to the execution of this agreement which is not expressly set out in this agreement'.

Where, as in the Maxfield case, Party A clearly has relied on pre-contractual statements, but signs a contract that contains an entire agreement clause that includes non-reliance wording, if Party B wishes to use the entire agreement clause as a defence to misrepresentations that have been made and relied upon, it is likely to be estopped from doing so. The only way around this is for Party B to be able to show that it genuinely believed that Party A had not relied on such statements, which was not the case here.

\section{Commentary}

Therefore, where you know that a statement has been relied upon, it is dangerous to expect that a non-reliance clause/entire agreement clause may come to your rescue. In fact, it is probably better under such circumstances to deal with such matters up front, and incorporate any such representation into your agreement so that all of the parties are clear on what has been represented and relied upon, and what has not.

Paul Langford, Professional Support Lawyer, Business \& Technology Services.

paul.langford@blplaw.com

\title{
Participation television: A breakdown of trust
}

Mimi Curran

Journal of Direct, Data and Digital Marketing Practice (2008) 9, 385-389. doi:10.1057/dddmp.2008.9

2007 was not a good year for the television industry. Revelation followed revelation of viewers being misled about television phone-in competitions (Richard and Judy), telephone voting systems (The $\mathrm{X}$-Factor) and generally in relation to winners and results of competitions (the naming of the Blue Peter cat). GMTV was fined $£ 2 \mathrm{~m}$ for its malpractice in the competitions that it has organised stretching back over a number of years. The primary concern related to contestants continuing to telephone (and be charged for the cost of the call) the competition telephone number long after the winner had been chosen, and GMTV's fine represents just one instance of many of the regulators taking a tough stance. 


\section{'Participation television'}

\section{Transparency}

Such problems have coincided with claims that certain so-called factual programmes have elements that have been staged, with the net result that viewers no longer seem to trust what they watch on television.

\section{What is participation television?}

'Participation television' is the broad category of programmes in which viewers can interact in some way with a programme, either during or after its broadcast. This can be by way of a phone-in quiz or with viewers calling in to vote for programmes such as Big Brother or the $\mathrm{X}$-Factor. All telephone calls made are charged at premium rates and prove extremely lucrative for the television company or broadcaster.

\section{ICSTIS}

The concerns over the operation of participation television, with its related dependence on premium rate telephone numbers, have not only prompted the television regulator Ofcom to take action, but also the premium telephone service regulator, ICSTIS.

ICSTIS has issued fines against broadcasters such as Channel Four in connection with the Richard and Judy competition and has also published new rules to 'boost consumer trust and confidence'.

\section{Transparency over the chances of getting through}

One of the criticisms levelled primarily against the quiz channels, such as ITV Play, was the fact that contestants had no idea whether they would be able to get through to take part in the quiz, despite spending (often a considerable amount of) time and money in their attempts.

ICSTIS has therefore introduced the requirement that viewers must be given information on screen in near real time in relation to the chances of acceptance or rejection of any attempt by a viewer to get beyond the first stage. The information must be updated at no more than ten-minute intervals.

\section{Pricing information}

Another key criticism made by ICSTIS was that viewers were not made properly aware of the cost of calls predominantly in relation to the quiz channels. Other programmes do, in fact, make pricing information available. With the introduction of new ICSTIS rules, whenever a premium rate service is used in connection with a viewer competition or quiz, information about the cost of calls will need to be given by either a presenter or a voice over at intervals of no more than ten minutes. Such information must also be accompanied by on-screen messages and by recorded introductions on the phone lines themselves.

\section{Call cost warnings}

Probably the biggest area of concern in relation to participation television was the fact that viewers could — and some did — run up 


\section{Warnings given}

\section{Consultation paper}

\section{Dedicated channels}

huge phone bills while taking part (or trying to take part) in the competitions offered particularly by the quiz channels.

Call cost warnings now have to be given to each caller when they spend more than $£ 10$ in each calendar day.

The new measures will undoubtedly help viewers to be better informed about the costs that they are likely to incur while playing the quizzes and competitions offered by the quiz channels. But the result for the channels themselves has been less positive. ITV Play, the competition service offered by ITV in the early hours of the morning, was once seen as ITV's financial saviour in the face of declining advertising revenues. It has now been taken off air because no one was playing. This is a trend pervading the industry. Now that customers know what it is costing them, the programmes have become much less attractive.

\section{Ofcom}

In addition to ensuring that consumers are properly protected, a key issue for Ofcom of participation television is to ensure the separation of advertising (in its broadest sense) from editorial. This principle is derived from the European Television Without Frontiers Directive, but recent developments in programming, such as the introduction of quiz television, have blurred the boundaries between advertising and editorial.

Ofcom, in its consultation paper published in July 2007, identifies the different types of participation television. It ranges from those programmes that feature some sort of participation as part of the main programme, such as Who Wants To Be A Millionaire, to those blocks of programmes or channels that are dedicated to a predicated genre, in terms of both content and funding of that content. Quiz channels fall within this latter category, as well as product offerings such as physic television.

The consultation paper addresses a number of issues, including how participation television should be regulated in the future. For programmes where participation is a part of the main programme, the proposals include making the broadcaster liable for all uses of premium rate telephone services and submitting to some form of audit and reporting process as a condition of its licence.

\section{Regulation of dedicated channels}

For dedicated channels, regulation is dependent - to a certain extent on the nature of the licence obtained. An editorial service, which is what most conventional broadcasters provide, allows for limited advertising and has strict rules in relation to how programmes can be funded. A teleshopping service allows the broadcast of direct offers to the public with a view to the supply of goods and services. It is not permitted to include any conventional programming in a teleshopping service. The third category is a self-promotional service that, as the name suggests, promotes a particular company's products although limited advertising of other products and services is also permitted. 


\section{Options}

Lottery
The issue for the dedicated channels is that the nature of the products and services they offer cannot otherwise be promoted on television as they are restricted products under the broadcast advertising codes. However, the 'editorial' offered is in some cases little more than a glorified infomercial for these types of products. Therefore, in order to restore customer confidence, Ofcom proposes other options for regulating these specialist channels.

\section{Ofcom options}

The options identified by Ofcom are:

- continue with the existing arrangements

- continue with the current categories of licence but introduce new rules in relation to the use of premium rate numbers, methods of payment, linking participation to editorial and provide for a definition of what constitutes dedicated participation television

- continue with the current categories of licence but require dedicated participation television to be clearly labelled as such on screen and

- categorise dedicated participation television as either teleshopping or self-promotion.

It is unlikely that the first of these options will be feasible. Television has moved on since the original licence conditions were introduced and regulation needs to reflect the changes that have occurred. The last of these options is also unlikely, as it would in fact mean the end of many forms of participation television that cannot be advertised under the current broadcast advertising codes. The most likely outcome is that either of options two or three are chosen, but this will depend on the result of Ofcom's consultation exercise.

\section{The Gambling Commission}

It is not just Ofcom and ICSTIS who have raised concerns in relation to participation television. The Gambling Commission has also signalled its interest in the sector. Prize competitions involving a degree of skill are not considered to be gambling and are therefore not regulated under the provisions of the Gambling Act 2005, which was fully implemented in September 2007. However, many of the quizzes and competitions featured on television do not require any level of skill to answer and therefore, in the view of the Gambling Commission, fall within the definition of a lottery.

This is because such competitions generally require payment to enter, prizes are allocated to one or members of a class and such relies wholly on chance. It is an offence under the gambling legislation to operate an unlicensed lottery. The Gambling Commission has put on notice that companies wishing to provide paid for competitions will need to add sufficient skill or face the penalties for offering an unlicensed lottery. 


\section{Commentary}

It has been a difficult period for the television industry, which knows that it has much to do to retain public confidence. The regulators concerned have shown that they are prepared to take action to protect viewers when appropriate. However, the financial implications for the television industry, which has relied heavily on income from premium rate competitions in the face of declining advertising revenue, have yet to become apparent. The mood is not optimistic.

Mimi Curran, Associate, Business \& Technology Services mimi.curran@blplaw.com

\section{Information technology: Industry deadline for two-hour mobile phone number porting}

\section{Tim Stevens}

Journal of Direct, Data and Digital Marketing Practice (2008) 9, 389-390. doi:10.1057/dddmp.2008.10

Ofcom rules
Ofcom has set new rules making it easier for consumers to keep their mobile number when they switch providers. Under the new rules, consumers will be able to receive calls using their existing number within two hours of moving to a new mobile network (down from five days).

\section{Simpler porting}

The move follows Ofcom's earlier decision to reduce mobile porting lead times from five days to two days from 1 April 2008. Two-hour transfers for mobile numbers must be implemented by 1 September 2009.

The rules will make it quicker and easier for consumers to keep their number and protect consumers from the risk of losing calls if their old provider's network fails.

In addition, industry will be obliged to ensure that the new porting process includes the necessary levels of protection for consumers.

\section{Common database to handle calls}

Ofcom is also requiring industry to cooperate to create a common database to handle calls and to pave the way for more efficient call routing.

The new database will make it possible to route calls to ported numbers directly to the new provider's network without the need for 